口原著

\title{
発達性読み書き障害児における聴覚法を用いた 漢字書字訓練方法の適用について
}

\author{
粟 屋 徳 子 ${ }^{*, * *}$ 春 原 則 子 ${ }^{* *, * * *}$ 宇 野 彰 ${ }^{* *, * * * *}$ 金 子 真 人*, **** $^{* * *}$ \\ 後 藤 多可志 ${ }^{* *}, * * *$ 狐 塚 順子 ${ }^{* *, * * * * * *}$ 孫 入里 英 ${ }^{* *}$
}

\begin{abstract}
要旨：発達性読み書き障害児に対し, 春原ら（2005）の方法に従って漢字の成り立ちを音声言語化 して覚える学習方法 (聴覚法) と書き写しながら覚える従来の学習方法（視覚法）の 2 種の漢字書 字訓練を行い聴覚法の適用を検討した。対象は発達性読み書き障害の小学 3 年生から中学 2 年生の 14 名で, 全例, 全般的知的機能, 音声言語の発達, 音声言語の長期記憶に問題はなかったが, 音韻 認識や視覚的認知機能, 視覚的記憶に問題があると考えられた。症例ごとに未習得の漢字を選択し， 視覚法と聴覚法の 2 通りの方法で訓練を行い, 単一事例実験研究法を用いて効果を比較した。その 結果， 2 例では両方法の間の成績に差を認めなかったが， 12 例では聴覚法が視覚法よりも有効であ った。この 12 例はいずれも, 視覚的認知機能または視覚的記憶に問題を認めた。この結果は, 聴覚 法による漢字書字訓練の適用に関する示唆を与えるものと思われた。
\end{abstract}

(高次脳機能研究 32 (2) ：294～301，2012）

\begin{abstract}
Key Words : 発達性読み書き障害, 漢字書字訓練, 聴覚法, 訓練効果, 視覚情報処理過程の障害 developmental dyslexia, training of Kanji writing, auditory method, training effectiveness, disorder in visual cognition
\end{abstract}

\section{はじめに}

developmental dyslexia は, 本邦では発達性読み 書き障害とも訳されている（大石 2001, 宇野ら 2002, など)。発達性読み書き障害が発達性高次脳 機能の障害の 1 つとして位置づけられ, 要素的な 認知機能評価により障害構造を推定することの重 要性 (大石 2001, 宇野ら 1995，1998，2003, 金 子ら 1997，1998，など）は本邦でも浸透してきた と思われる（粟屋ら 2003, 宇野ら 2007, 河村ら 2007, 蔦森ら 2009)。しかし, 推定された障害構 造にもとづく訓練方法について，その効果を科学 的定量的に測定した報告は多くはない（Brunsdon ら 2005, Rowse ら 2007, Berninger ら 2008)。当
然のことながら，漢字書字に関しても本邦で散見 されるのみである（宇野ら 1998，川崎ら 2005， 春原ら 2005, 藤吉ら 2010)。このうち春原ら （2005）は，3例の発達性読み書き障害児に対して 漢字の成り立ちを音声言語化して覚える学習方法 (聴覚法) と書き写しながら漢字を覚える従来の学 習方法 (視覚法)を行い，効果の持続という点にお いて前者が有用であったと報告している。しかし， その適用について詳細な検討はなされていない。

本研究の目的は, 発達性読み書き障害児 14 例に 対し漢字書字訓練を聴覚法と視覚法の 2 種類の方 法にて行い, 聴覚法の適用に関して検討すること である。

\footnotetext{
*東京都済生会中央病院 リハビリテーション科 $\bar{\top}$ 108-0073 東京都港区三田 1-4-17

受稿日 2011 年 6 月 20 日

${ }^{* *} \mathrm{LD}$ ・ Dyslexia センター

受理日 2011 年 12 月 31 日

***目白大学 保健医療学部 言語聴覚学科

***** 筑波大学大学院 人間総合科学研究科

******帝京平成大学 健康メデイカル学科

*******埼玉県小児医療センター
} 


\section{I. 対象（表 1)}

通常学級在籍の小学 3 年から中学 2 年の男児 9 名，女児 5 名の計 14 名で，全例右利きである。い ずれも専門機関にて，要素的な認知機能検査や読 み書きに関する学習到達度検査などから, 発達性 読み書き障害と診断評価されている。症例 3 は小 学 5 年時に注意欠陥/多動性障害 $(\mathrm{AD} / \mathrm{HD})$, 症例 4 は小学 4 年時に注意欠陥障害 (ADD), また症例 10 は口蓋裂を認め, 症例 12 は 5 歳時に広沉性発達 障害の診断を受けていた。症例 13 は生後数カ月時 にカブキ症候群の診断をうけており, 就学時は粗 大運動において若干の速度の遅さがあったが，そ の後明らかな運動発達の遅れは認められなかった。
その他の症例では生育歴に特記事項はない。

全例，WISC-IIIの言語性 IQ，動作性 IQ のいず れかが 90 以上であった。語彙発達の指標のひとつ として実施した標準抽象語理解力検査（春原ら 2002, 以下 SCTAW） は，聴覚-指差し課題にて全 例同学年健常平均範囲内の得点であった。

症例 1 を除く中学 1 年生の 2 名には小学生の読 み書きスクリーニング検査（宇野ら 2006, 以下 STRAW）の小学 6 年生用を, 小学生 11 例にはそ れぞれの学年の課題を実施し，全例カタカナと または漢字で，同学年健常平均に比し得点低下が 認められた。症例 1 は中学 2 年生であったため小 学生を対象としたSTRAW は使用せず, 小学 5 年 配当漢字 10 単語と, それを仮名書きした単語の読

表 1 全例の読み書き能力

\begin{tabular}{|c|c|c|c|c|c|c|c|c|c|c|c|c|c|c|}
\hline & & 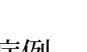 & & & HCS & & & & & 読 & 从書き能 & 力の到達 & 度 & \\
\hline & & & & & & & RCPM & & STRAI & V（単語 & 音読） & STRAI & W（単語 & 書取) \\
\hline & 学年 & 利き手 & 性別 & VIQ & PIQ & FIQ & & 32 課題 & ひら & カタ & 漢字 & ひら & カタ & 漢字 \\
\hline 1 & 中 2 & 右 & 男 & 94 & 101 & 97 & 0.56 & -1.13 & 0.00 & 0.00 & $-2.00 *$ & $-5.00 *$ & $-5.00^{*}$ & $-1.54^{*}$ \\
\hline 2 & 中 1 & 右 & 男 & 100 & 124 & 112 & -0.54 & 0.38 & 0.25 & $-1.80 *$ & $-3.04 *$ & 0.15 & $-3.00^{*}$ & $-2.59 *$ \\
\hline 3 & 中 1 & 右 & 男 & 100 & 104 & 102 & -0.77 & -0.71 & 0.25 & 0.20 & 0.30 & 0.15 & -0.50 & $-2.40^{*}$ \\
\hline 4 & 6 年 & 右 & 男 & 96 & 80 & 88 & 0.04 & 1.60 & 0.00 & 0.50 & 0.53 & 0.62 & -0.23 & $-1.72^{*}$ \\
\hline 5 & 6 年 & 右 & 女 & 97 & 79 & 88 & 0.04 & 0.85 & 0.00 & $-5.00 *$ & $-3.54 *$ & $-3.71 *$ & $-2.67^{*}$ & $-2.05^{*}$ \\
\hline 6 & 5 年 & 右 & 男 & 95 & 92 & 93 & 0.31 & 0.60 & 0.00 & 0.50 & -0.13 & 0.62 & 0.68 & $-3.24^{*}$ \\
\hline 7 & 5 年 & 右 & 女 & 91 & 83 & 86 & -1.37 & 1.02 & 0.00 & 0.00 & 0.70 & $-2.25 *$ & $-2.57^{*}$ & $-3.00^{*}$ \\
\hline 8 & 5 年 & 右 & 男 & 110 & 104 & 108 & -0.24 & 0.85 & 0.00 & 0.50 & 1.20 & -0.15 & -0.23 & $-2.37^{*}$ \\
\hline 9 & 5 年 & 右 & 女 & 90 & 93 & 90 & 0.54 & -1.40 & 0.00 & 0.00 & 1.08 & 0.06 & $-1.56^{*}$ & $-3.95 *$ \\
\hline 10 & 4 年 & 右 & 男 & 87 & 97 & 91 & -0.14 & 0.31 & $-5.00^{*}$ & 0.20 & $-3.82 *$ & $-1.89 *$ & -0.95 & $-2.54^{*}$ \\
\hline 11 & 4 年 & 右 & 男 & 105 & 99 & 102 & 0.48 & 0.07 & $-5.00^{*}$ & $-1.80 *$ & $-3.82 *$ & 0.21 & 0.41 & $-3.27^{*}$ \\
\hline 12 & 3 年 & 右 & 男 & 115 & 80 & 99 & 0.54 & 0.56 & $-4.75^{*}$ & $-8.67^{*}$ & $-6.28 *$ & $-7.73 *$ & $-3.09 *$ & $-4.28^{*}$ \\
\hline 13 & 3 年 & 右 & 女 & 96 & $75^{*}$ & 85 & 0.28 & 0.77 & 0.00 & 0.33 & 0.00 & 0.33 & -0.36 & $-8.14^{*}$ \\
\hline 14 & 3 年 & 右 & 女 & 116 & 113 & 116 & 1.09 & -0.48 & 0.00 & 0.33 & $-4.44 *$ & 0.33 & $-2.18^{*}$ & $-8.14^{*}$ \\
\hline
\end{tabular}

WISC - III 以外の数値は $z$ 得点化した数值（*は得点が- 1.5 未満のもの)

RCPM : レーブン色彩マトリックス検査

SCTAW：標準抽象語理解力検査

STRAW : 小学生の読み書きスクリーニング検査

(RCPM.SCTAW.STRAW いずれも $\quad z$ 得点は小学通常学級 3 年生から 6 年生までの 883 名 宇野ら 2006 より算出した) 
み書きを実施したが，特に漢字書字において 282 例の同学年健常平均に比し明らかな得点低下が認 められた。

音韻認識検査としては，3，4 モーラの単語逆唱 (各 10 課題) と 4 から 8 モーラの非語復唱（10 課 題）を実施した。単語逆唱は復唱してから行い, 正答率と正答までの所要時間を測定した。10例で 音韻認識検査のいずれかの項目で典型発達例に比 して得点低下が認められた。一方, 聴覚的言語記 憶の検査である Rey の Auditory Verbal Leaning Test（AVLT）は全例 30 分後の遅延再生において 15 語中 11 語以上可能であった。

視覚的認知機能の指標として, Rey-Osterrieth Complex Figure Test (ROCFT) の模写と, Matching Familiar Figure Test（MFFT）もしくは日本人向け に独自に作成した線画同定課題を実施した。 MFFT と日本人向けの線画同定課題はいずれも, 猫や鉛筆など小児でもよく知っている事物の線画 を用いてターゲットと同じ絵を類似する 6 枚の絵 の中から同定する課題である。誤答した場合は, 正答できるまで修正が求められる。初発反応で正 答できた項目数 (正答数), 初発反応までの時間, 正答までに繰り返された誤反応の回数（誤答数） を測定した。さらに, 視覚的記憶の指標として, ROCFT の直後および 30 分後遅延再生を行った。 採点は 36 点を満点とする方法に加えて, 視覚的認 知機能や構成能力などの影響を最小限にするため, 後藤ら（2010）の方法に従い, 模写課題の得点を 分母に, 直後再生や遅延再生課題の得点を分子と した割合も算出した（以下，視覚性記憶率）。その 結果 5 例で, ROCFT の模写の得点や, MFFT ある いは線画同定課題の正答数が同学年健常平均より も有意に低いか，もしくは誤答数が多かった。残 り 9 例のうち 6 例は, ROCFT の直後 - 遅延再生双 方で同学年健常平均に比し得点が低く, 1 例（症 例 14）は視覚性記憶率が50\%であった。なお， ROCFT の $z$ 得点を算出した健常群（小学 3 年生の 典型発達児 134 名）の視覚性記憶率は, 小学 3 年 (直後 /模写, 遅延/模写, のそれぞれ) で $56.8 \%, 57.9 \%$ あっった。残りの 2 例では，これ らの視覚性認知機能の課題の成績に明らかな低下 は認められなかった。

\section{II. 方 法}

\section{1. 開始条件}

ひらがな, カタカナの書字に問題がない，ある いは訓練にてひらがな, カタカナ清音の書字がほ ほ $100 \%$ 可能になった時点で, 漢字書字の訓練を 開始した。いずれも本人と保護者に説明し同意を 得た。

\section{2. 訓練語の選定}

症例ごとに，使用する漢字を 20 から 40 文字選 択した。小学 3 から 5 年生のうちの 7 例は未学習 の学年の配当漢字から選択した。残りの 7 例は, 少なくとも 2 回以上書き取りが不可の漢字を選定 した。これらの漢字を，文字数や画数を統制して 2 群に分け，I群は視覚法，すなわち書き写しな がら覚える通常の方法で, II 群は聴覚法（以下に 記載)で行った。

\section{3. 聴覚法}

構成要素の成り立ちを漢字ごとに一つの文にし て, 暗唱しながら覚える方法である（例「給」： 症例 13 「給食の時間に糸を合わせる」, 症例 12 「給食のあと, 糸を使ってとんがり屋根 (^)の下 の二匹の只バをつれてくる」…注 ; 下線部_は漢 字の構成要素を示す)。対象児と相談し，一文字ず つそれぞれに合わせて文を作成した。文作成には， (1)上から，または左から始める順序，(2)目標文字 を含む単語を文頭にする，(3)対象児の既知の語で 構成し, かつ本人が納得したものとすることなど を原則とした。

\section{4. 実験デザイン}

訓練は両方法とも全例連続 5 日実施し, 練習時 間も両方法で同一にした。1日あたりの練習時間 は，対象児の集中可能な時間を考慮し，10〜 15 分の間で本人に決めさせた。

実験デザインは，ベースライン期の後，I 群の 漢字書字練習を視覚法にて 5 日間行い, その翌日 に訓練語の書字正答率を確認（視覚法第 1 時点）し た。視覚法での練習と効果測定終了後, II 群の漢 字書字練習を聴覚法にて 5 日間実施し, その翌日 に訓練効果を測定した（聴覚法第 1 時点）。両方法 ともに練習期間の約 2 週後（第 2 時点）と約 4 週 後 (第 3 時点)にフォローアップの評価を実施した。 


\section{5. 分析}

第 1 時点における $2 つ の$ 訓練法の効果をマクネ マー検定にて検討した。また，両方法での正答率 の差をフィッシャーの直接確率法検定にて比較し た。要素的な認知機能は, 各症例の学年が異なる ため $z$ 得点化して検討した（表 2）。

訓練効果に関連する要素的な認知機能は，マン ホイットニーU 検定にて比較した。検定には Excel 2010 およびSPSS 16.0 を用いた。

\section{III. 結 果}

全例，ベースライン期の正答率は $0 \%$ であった。 全例, 聴覚法においてはベースライン期と比較し て第 1 時点の正答数が有意に増加した $\left(\chi^{2}=8.10\right.$ $\sim 15.06, \mathrm{df}=1, \mathrm{p}<.001)$ 。視覚法による第 1 時 点の正答数は, 7 例において有意に増加した $\left(\chi^{2}=\right.$ $4.17 \sim 15.06, \mathrm{df}=1, \mathrm{p}<.05)$ 。第 1 , 第 2 , 第 3 時点における正答率の推移は, 以下の 3 パターン に分かれた（図1）。1つめは，第1時点ですでに 聴覚法での正答率が視覚法よりも有意に高いパ夕 ーン $\left(\chi^{2}=5.00 \sim 16.43, \mathrm{df}=1, \mathrm{p}<.05\right)$ で, 10 例で認められた。2つめは, 第 1 時点での正答率 は両方法で差がなかった（ $\chi^{2}=2.14 \sim 3.33, \mathrm{df}=$ $1, \mathrm{p}>.05)$ が，維持期において聴覚法が有意に良 好となったパターンで, 症例 $3\left(\chi^{2}=6.00, \mathrm{df}=1\right.$, $\mathrm{p}<.05)$, 症例 $9\left(\chi^{2}=20.00, \mathrm{df}=1, \mathrm{p}<.001\right)$ の 2 例で認められた。3つめは, 練習直後, 維持 期ともに両方法で正答率に差がみられなかったパ ターンで, 症例 1,4 の 2 例が該当した（各々 $\chi^{2}=$ $0.13 \sim 0.18, \mathrm{df}=1, \mathrm{p}>.05, \quad \chi^{2}=0.04 \sim 0.14$, $\mathrm{df}=1, \mathrm{p}>.05)$ 。

以上の 3 つのパターンに分類された 3 群につい て，要素的な認知機能（表 2）を比較したところ, 「訓練終了直後から聴覚法が良好」な群と「維持期 に聴覚法が良好」な群との間には明らかな差は認 められなかった。そこで，このふたつの群を合わ せて「聴覚法がより有効」な群とし，「訓練方法間 の練習成績に有意差のない」パターンを示した群 と比較した。その結果, MFFTの正答数と誤答数 の 2 項目で 2 群間に有意差が（各々 $\mathrm{U}=0.03$, $\mathrm{p}<.05, \mathrm{U}=0.03, \mathrm{p}<.05)$, ROCFT 直後再生の 記憶率で有意傾向が認められた（U=0.07， $\mathrm{p}=.08)$ 。一方, その他の課題では有意差は認めら れなかった。

この，「聴覚法がより有効」というパターンを示 した 12 例をみると，5例は図形同定課題の正答数 が健常平均に比して少ないか，または誤答数が多 かった。残りの 7 例中また 6 例では，ROCFT 直後 および遅延再生で有意な低下が認められ，残りの 1 例は ROCFT の視覚記憶率が $50 \%$ あっった。一 方，「訓練方法間の練習成績に有意差なし」のパ夕 ーンを示した症例 1 と 4 は, MFFT初発反応時間 以外の視覚情報処理過程の検査では得点低下を示 さず，視覚性記憶率も $60 \%$ 以上であった。

\section{IV. 考察}

\section{1. 漢字の聴覚法書字訓練の適用}

今回対象とした 14 例の発達性読み書き障害児は 全例で, 音声言語の記憶を活用して漢字書字を学 習する聴覚法において従来の学習方法による結果 と同等，もしくはそれ以上の効果が認められたこ とから，聴覚法は有用であったと考えられた。聴 覚法は漢字の構成要素の成り立ちを文にして覚え る方法であり, 聴覚的言語記憶を活用する必要が ある。今回の対象児はすべて, 全般的知的能力や 音声言語能力に明らかな問題はなく，また，AVLT の結果から聴覚的言語記憶も良好と考えられた。 聴覚法による漢字書字学習には，これらの共通事 項が必要な要因ではないかと考えられた。

さらに，視覚法に比し聴覚法での学習効果が有 意に高い症例が 12 例いた。この 12 例のうち 5 例 は視覚的認知機能の問題を認め, 症例 14 を除く残 りの 7 例は視覚的記憶に問題があると考えられた。 また症例 14 についても，視覚情報処理過程に関す る得点は低めであった。すなわち, 視覚的認知能 力や視覚的記憶のどちらか一方でも問題が認めら れる場合は, 従来の何回も写して書くという視覚 法による漢字学習は必ずしも有用でないという可 能性が考えられる。

英語圈においても本邦においても，これまで音 韻障害が発達性読み書き障害の背景要因として重 視されてきた。しかし一方で，近年の英語圈では 視覚情報処理過程障害仮説についても, Stein （2001）を中心とする magnocelluler 障害説， 


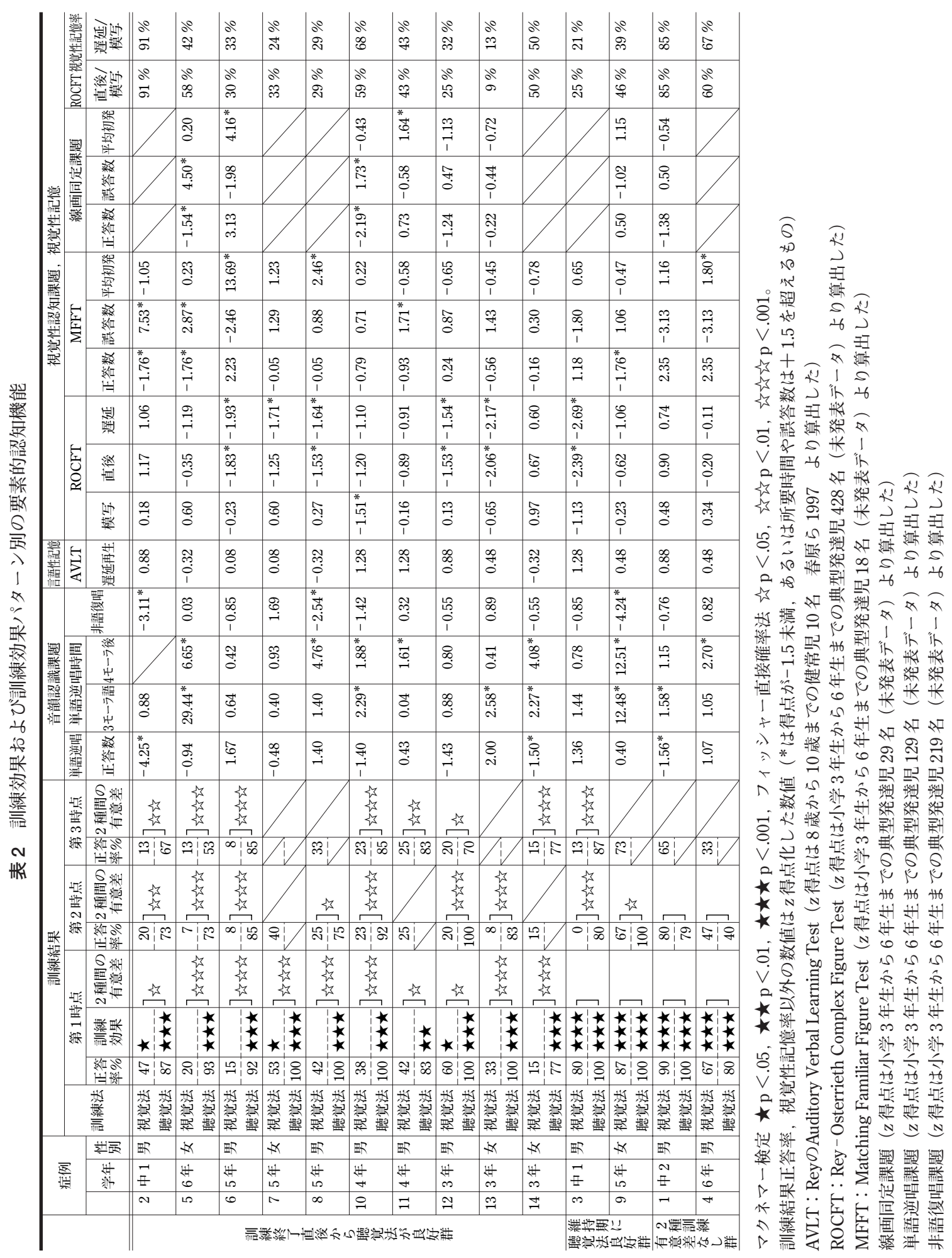




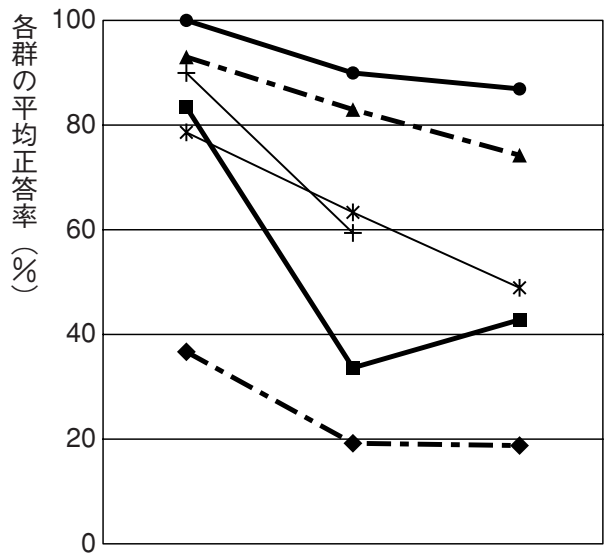

第 1 時点 第 2 時点 第 3 時点

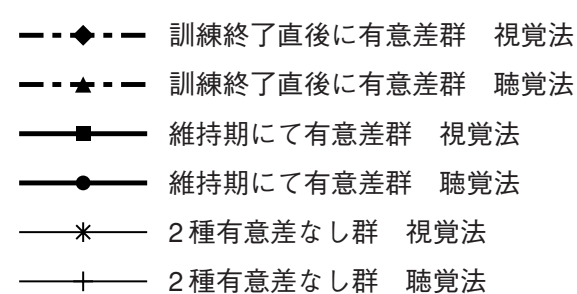

図1 訓練効果パターン別・各群平均正答率の推移

Winner ら（2001）の視覚性空間処理（visual-spatial）障害説，Bosse ら（2007）の視覚性注意障害 説などさまざまな説が提唱されている。本邦では 宇野ら（2002）が，発達性読み書き障害児 22 名に 認知神経心理学的検討を行った結果，聴覚情報処 理過程に関する検查得点のみが低下していた症例 は 1 例のみで，16例では音韻障害処理過程と視覚 情報処理過程双方の障害を認め，視覚情報処理過 程に関する得点のみが低下していた症例も 5 例い たと報告している。

漢字書字の学習には, 手本となる漢字の視覚的 認知, 視覚的記銘と保持, 漢字図形の想起再生と いう情報処理過程が必要とされており（井潤ら 2001）, これらの過程の障害が漢字書字障害の要因 になる可能性が考えられている（井潤ら 2001, 川 崎ら 2005)。本研究の 14 症例のうち視覚的認知機 能もしくは視覚的記憶に問題があった 12 例も，視 覚的情報処理能力の脆弱性によって漢字学習が阻 害されているものと考えられた。一方, 聴覚法と 視覚法の 2 種類の漢字学習方法において有意差が 認められなかった 2 例では，いずれも視覚的認知 機能, 視覚的記憶に明らかな問題はないと考えら れた。そのため，文字を書き写しながら覚えると いう従来の方法でも, 練習する文字数をコントロ ールして集中的に行ったことにより学習の効果が 得られたのではないかと考えられる。

読み書き障害の背景に視覚的情報処理能力の問 題があると推測され，かつ，全般的知的機能や言

語発達および聴覚的言語性記憶が保たれている場 合には, 聴覚法による漢字学習の適用のあること が示唆されたのではないかと思われた。

\section{2. 長期的な訓練効果判定の必要性}

今回認められた「訓練直後には 2 つ方法で有 意差がなかったにもかかわらず, 維持期において 聴覚法がより有効であった」群の存在は，2種の 方法による訓練効果の評価が長期的に行われる必 要のあることを示唆している。さらに，長期間を 経た後の評価は, 訓練効果の維持期間に関する客 観的目安ともなり, 復習を行う時期についての有 用な情報ともなり得るのではないかと思われる。

\section{3. 書字訓練の実用性}

春原ら（2005）が指摘するように，新しい訓練 方法の導入にあたっては開始前に十分な評価を行 ったうえで個々の認知特性に適した効果をあげう る方法を見極めること，および対象児自身（およ びその保護者）の十分な納得を得ることが重要と 思われる。児童本人が納得をして練習に取り組め るかどうかは, 意欲やその後の練習継続の成功に も大きく影響すると思われる。

今回実施した聴覚法は, 本人が納得できるかた ちで漢字の成り立ちを音声言語化し, 対象例それ ぞれに応じた文を作っていく。そのため, 練習期 間終了後にも記憶が保持されやすかったのではな いかと考えられる。また, 漢字の中にその児童に とって既知の形を見つけ，それらを音声言語化し ていく作業を繰り返すことによって，本人が自発 
的に複雑な漢字を分解して覚える手段を獲得する 可能性が高まっていくと考えられる。反対に, 聴 覚法は納得した文を作成する必要があるため, 通 常の学習方法にくらべ時間や手間がかかることは 否めない。教育漢字すべてを健常児と同じように 習得するには時間的に困難な場合が多く, 児童の 将来に向けて, 実用性という観点から電子辞書や パソコンなどの電子機器といった代償的手段に関 する指導も行っていくべきであると思われる。

\section{文献}

1) 粟屋徳子, 宇野 彰, 庄司敦子, ほか：音韻処 理能力と視覚情報処理能力の双方に障害を認め た発達性書字障害児の 1 例. 小児の精神と発達, 43 : 131-138, 2003.

2 ) Berninger, V. W., Nielsen, K. H., Abbott, R. D., et al. : Writing problems in developmental dyslexia ; Under-recognized and under-treated. Journal of School Psychology, 46 : 1-21, 2008.

3 ) Bosse, M. L., Tainturier, M. J. \& Voldois, L. : Developmental dyslexia - the visual attention span deficit hypothesis. Cognition, 104 (2) : 198230, 2007.

4) Brunsdon, R., Cotheart, M. \& Nickels, L. : Treatment of irregular word spelling in developmental surface dysgraphia. Cognitive Neuropsychology, 22 (2) : 213-251, 2005.

5 ) 藤吉昭江, 宇野 彰, 川崎聡大, ほか：漢字書 児困難児における方法別の書字訓練効果一単語 属性条件を統制した単語群を用いた検討一。音 声言語医学, $51 ：$ 12-18, 2010.

6 ) 後藤多可志, 宇野 彰, 春原則子, ほか: 発達 性読み書き障害児における視機能, 視知覚およ び視覚認知機能について。音声言語医学, 51 : 38-53, 2010.

7 ) 春原則子, 宇野 彰, 平野 悟, ほか: 記憶障 害を主症状とする小児の 1 例。脳と発達, 29 ： 321-325, 1997.

8 ) 春原則子, 金子真人, 著, 宇野 彰, 監修: 標
準抽象語理解力検査. インテルナ出版, 東京, 2002.

9）春原則子, 宇野 彰, 金子真人：発達性読及書 き障害児に打ける実験的漢字書字訓練一認知機 能特性に基づいた訓練方法の効果一。音声言語 医学, 46 : 10-15, 2005.

10）井潤知美, 宇野 彰, 小林美緒：かなに比べて 漢字に強い読み書き障害を呈した 1 例. 小児の精 神と神経, 41：169-173, 2001.

11）金子真人, 宇野 彰, 加我牧子, ほか：漢字仮 名双方に読み書きの障害を認めた学習障害児に おける平仮名 1 文字の読み書き過程。脳と発達, 29 : 249-253, 1997.

12）金子真人, 宇野 彰, 春原則子, ほか：仮名と 漢字に特異的な読み書き障害を示した学習障害 児の仮名書字訓練。音声言語医学，39：274278, 1998.

13）河村 暁, 新妻由希枝, 益田 慎, ほか：ワー キングメモリに困難のある LD 巟の漢字の読み書 き学習に打ける単語の熟知度と漢字の画数・複 雑性の影響. LD 研究, 16：49-61, 2007.

14）川崎聡大, 宇野 彰: 発達性読及書き障害児 1 例 の漢字書字訓練。小児の精神と発達, 42：177181, 2005.

15）大石敬子 : 発達性読み書き障害のリハビリテー ション. 失語症研究, $21 ： 185-193,2001$.

16) Rowse, H. J. \& Wilsire, C. E. : Comparison of phonological and whole-word treatments for two contrasting cases of developmental dyslexia. Cognitive Neuropsychology, 24 (8) : 817-842, 2007.

17) Stein, J. : The magnocellular theory of developmental dyslexia. Dyslexia, 7 : 12-36, 2001.

18）蔦森英史, 宇野 彰, 春原則子, ほか：日本語 での音韻認識障害が認められない英語学習困難 例. 音声言語医学, $50 ： 167-172,2009$.

19）宇野彰, 加我牧子, 稲垣真澄: 漢字書字に特 異的な障害を示した学習障害の 1 例一認知心理学 的および神経心理学的分析一. 脳と発達, 27 : 
395-400, 1995.

20）宇野 彰, 金子真人, 春原則子, ほか：学習障 害児の英単語書き取りに打ける実験的訓練効果 研究. 音声言語医学, 39：210-214, 1998.

21）宇野 彰, 金子真人, 春原則子, ほか：発達性 読み書き障害一神経心理学的および認知神経心 理学的分析一. 失語症研究, $22 ： 130-136,2002$.

22）宇野 彰, 金子真人, 春原則子：学習障害児に 対するバイパス法の開発一機能障害に関するデ 一タに基づいた治療教育一。発達障害研究, 24 : 348-356, 2003.

23）宇野 彰, 春原則子, 金子真人, ほか：小学生
の読み書きスクリーニング検査一発達性読み書 き障害（発達性 dyslexia）検出のために一。イン テルナ出版, 東京, 2006 .

24）宇野 彰, 春原則子, 金子真人, ほか：発達性 Dyslexia の認知障害構造一音韻障害単独説で日本 語話者の発達性 Dyslexia 説明可能なのか? 音声医学言語, $48 ： 105-111,2007$.

25) Winner, E., von Karoly, C., Malinsky, D., et al. : Dyslexia and visual-Spatial Talents - Compensation vs Deficit Model. Brain and Language, 76 : 81-110, 2001.

\section{Abstract}

\section{Training Method Using Auditory Memory of Kanji Writing in Japanese Children with Developmental Dyslexia}

\section{Noriko Awaya*, ** Noriko Haruhara**, *** Akira Uno**,**** Masato Kaneko**, ***** Takashi Goto**, *** Junko Kozuka**, ****** Rie Sonnyu**}

We investigated the efficacy of two types of learning methods for Kanji writing in 14 Japanese children with developmental dyslexia. 12 were third to sixth graders in Japanese primary schools, and the other two were seventh or eighth graders in Japanese junior high schools. One method was similar to that traditionally taught in schools (visual method), and the other consisted of memorizing the construction of Kanji characters orally (auditory method). Although the participants had average intelligence, language ability, and ability in auditory memory, they had disorders of phonological awareness and/or visual cognition including visual perception and memory. All participants improved in learning Kanji writing through the auditory method, and in 12 of the 14 participants this method was more effective than the visual method. These 12 participants had disorders of visual cognition and/or visual memory. Results were not significantly different between the two methods for the two participants who did not have disorders of visual cognitive processing. Results suggest the benefit of applying the auditory method to learning Kanji characters in Japanese children with developmental dyslexia.

${ }^{*}$ Department of Rehabilitation, Tokyo Saiseikai Central Hospital. 1-4-17, Mita, Minato-ku, Tokyo 108-0073, Japan

${ }^{* *} \mathrm{LD} /$ Dyslexia Centre

${ }^{* * * *}$ Faculty of Health Sciences, Mejiro University

${ }^{* * * * *}$ Graduate School of Comprehensive Human Sciences, University of Tsukyba

${ }^{* * * * * *}$ Faculty of Medical Science, for Health, Teikyo Heisei University

******* Saitama Children's Medical Center 